FOCUS ON: CELLS

\section{CELL AND}

MOLECULAR BIOLOGY OF THE CYTOSKELETON

edited by Jerry $\mathbf{W}$. Shay

A thorough exploration of the cytoskeleton's molecular, biochemical, and structural properties with an emphasis on how they function in the living cell. Among the outstanding contributions in this volume are chapters on the structural aspects of intermediate filaments, molecular mechanisms controlling tubulin syn thesis, probing the cytoskeleton by microinjection, and actin - a regulator of cell growth and differentiation. 0.306-42175-5/356 pp./ill./1986\$49.50 (\$59 40 outside US \& Canada)

\section{VIDEO}

\section{MICROSCOPY}

\section{by Shinya Inoué}

A practical handbook for those getting started in video microscopy. The basics of both video and microscopy are reviewed and sufficient theory is provided to aid in the selection and use of video microscopy equipment. A list of hard-to-find pamphlets - along with the addresses of their sources - and a glossary - with relevant section numbers included for each en try - are among the many features that make this a valuable reference as well as a practical handbook. 0-306-42120-8/612 pp./ill./1986/\$65.00 (\$78.00 outside US \& Canada) text adoption price on orders of six or more copies: $\$ 37.50$

\section{INTERACTION} OF CELLS WITH NATURAL AND FOREIGN

\section{SURFACES}

edited by N. Crawford and D. E. M. Taylor

One of the few interdisciplinary works to focus on the morphological and physiochemical aspects of cell-cell surface interactions and cell-foreign or natural surface interactions. Topics include electrokinetic properties of membranes, biotolerance, vascular grafts, sutures, and biocompatiability 0-306-42373-1/proceedings/368 pp + index ill./1986/\$59.50 (\$71.40 outside US \& C.anada)

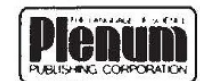

Plenum Publishing Corporation 233 Spring Siree New York, N.Y. 10013.1578 In the United Kingdom: 88/90 Middlesex Street London EJ 7EZ, England

\section{Other sides of the astronomer}

\section{Robert S. Westman}

Nicholas Copernicus: Complete Works. Vol. III Minor Works. Edited by Paul Czartoryski. Translation from the Polish edition and commentary by Edward Rosen with the assistance of Erna Hilfstein. Macmillan, London: 1986. Pp.380. £60.

FEw scientists and general readers are aware that Copernicus's first published work (1509) was a translation from Greek into Latin of a book entitled Ethical, Rustic, and Love Letters by an obscure ninth-century Byzantine writer named Theophylactus Simocatta. "Your natural beauty has faded and your good looks are approaching [the stage of] wrinkles", so opens letter No. 3. "But you try to give the impression of truth when you deceive your lovers with artificial cosmetics. Hearken to time, you hag, for in the autumn meadows are not the place for flowers." Etc. It is good fun and a fine way for a young humanist to sharpen his Greek. And, because Copernicus's Greek dictionary has survived, it is possible to see just how good his Greek was given the lexicographical tools at his disposal. Because every letter in his dictionary began with a capital letter, he could never be certain that he was considering a proper or a common noun. In letter 31 , the peacock is described by Simocatta as "the Persian bird" who acquires "the arrogance of the Persians", but Copernicus produced instead "an active bird" that took on the "splendor of the energetic birds" (p. 8).

In 1517 , Copernicus, a canon or administrative official of the Warmia chapter of the Church, composed a Latin treatise on the urgent matter of the debasement of coinage; two years later, at the behest of the West Prussian Estates, he prepared a German version that differs in certain respects from the first. "It is not the least advisable to introduce a new, good coinage", wrote Canon Copernicus, "while an old, debased coinage remains in circulation. How much worse was this mistake, while an old, better coinage remained in circulation, to introduce a new debased coinage, which not only spoiled the old coinage but, so to say, swept it away!" (p. 187).

The passages cited above are but two examples of the rich feast to be found among the "minor works" of Nicholas Copernicus, a figure otherwise known in the history of science for daring to propose that the Earth and the other "elements" beneath the Moon revolve annually around a motionless Sun. To be sure, astronomical writings are not missing from this volume: the Commentariolus, Copernicus's first formulation of the heliocentric hypothesis, probably written sometime between 1508 and 1514, and not published in Copernicus's lifetime; the Letter Against Werner (1524), which attacks Johann Werner's treatise on the motion of the sphere of the fixed stars but deferring to another occasion the author's own views on whether that sphere moves or not. In addition, one finds translations of all 17 extant letters written by Copernicus as well as a group of administrative documents. Copernicus had studied medicine at Padua; in one of his books, one finds a prescription for pills that promises to do the following:

harmlessly eliminate whatever is excessive.. postpone gray hair, which comes from corrupt humors ... repress catarrh, stop a cough, relieve the congestion... alleviate gas in the stomach... sharpen the wits, strengthen and invigorate the nerves, preserve the teeth from decay...induce sleep....and purge gently [p.301]

Vast talents and international energies went into the preparation of this volume. Professor Paul Czartoryski, general editor of the Complete Works, deserves the highest praise for the difficult task of coordinating the Polish and American research teams. His job was not an easy one. Although the late Edward Rosen, assisted by Erna Hilfstein, produced the English translation, their work built significantly but with thin acknowledgement upon the Polish contributions. Few of the scholars mentioned in Czartoryski's detailed introduction, such as Jerzy Dobrzycki and Jerzy Drewnowski, are referred to in Rosen's notes; indeed, scholars will need to consult the Polish edition for material arbitrarily excluded by Rosen and Hilfstein.

On the other hand, a veritable firestorm of polemic fills Rosen's footnotes to the Commentariolus (pp. 91-126) where Noel Swerdlow (baptized as "Sw" in order to eliminate him from the Citation Index!) is roasted to a crisp for having had the temerity to translate anew in 1973 Rosen's supposedly canonical 1939 version of that same work. Rosen has now adopted some of Sw's language in this new translation without acknowledgement. The principle of ignoring what you take from others while castigating them for their minor peccadilloes, real or imagined, seems here to have been raised to the status of a major editorial axiom. Copernican specialists will easily spot these off-the-text dog fights; general readers will probably miss them (without loss). Everyone will benefit from what is left over: a much richer picture of Copernicus as a Renaissance humanist, church astronomer and man of practical action.

Robert $S$. Westman is a Professor in the Department of History, University of California, Los Angeles, California 90024, USA. 